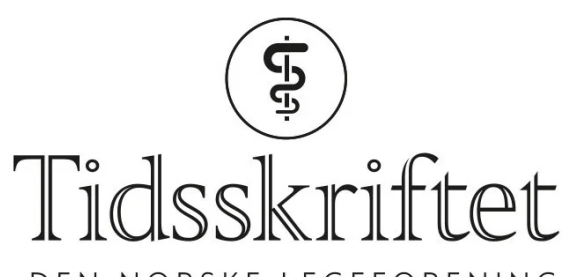

DEN NORSKE LEGEFORENING

\title{
Fremkalte eller relaterte hendelser?
}

SPRÅKSPALTEN

\section{FRANK BECKER}

Email: frank.becker@sunnaas.no

Klinikk for hjerneskader

Sunnaas sykehus

1450 Nesoddtangen

og

Institutt for sykehusmedisin

Universitetet i Oslo

Elektrisk aktivitet som oppstår i relasjon til stimuli bør betegnes som «hendelsesrelaterte potensialer». Dette bør være den norske betegnelsen for både «evoked potentials» (EP) og «event-related potentials» (ERP).

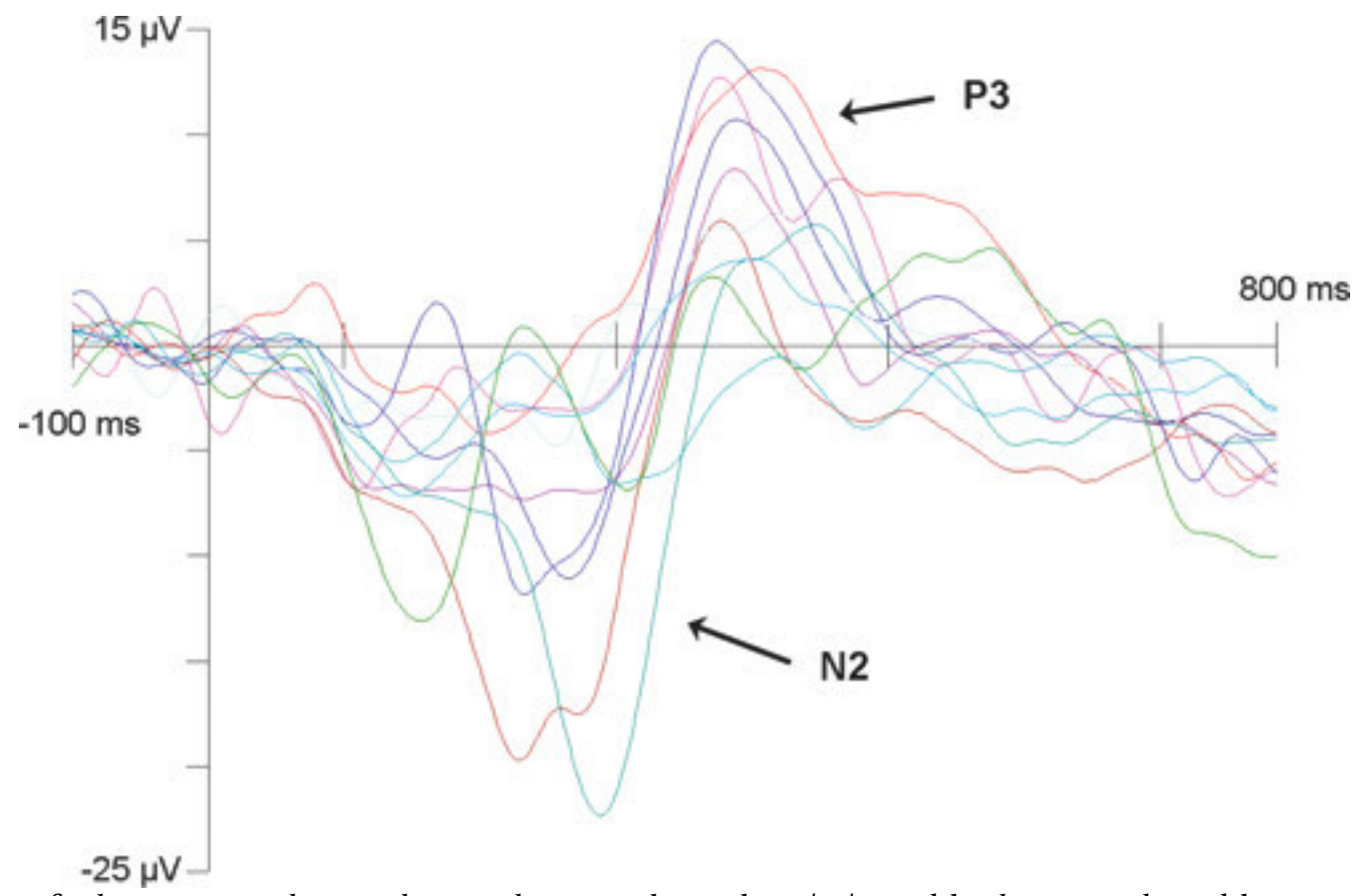

11 friske personers hjerneaktivitet knyttet til stavelsen/ta/ som ble aktivt oppdaget blant standardstavelsen /ba/ (elektrode: Pz). De hendelsesrelaterte potensialene $\mathrm{N}_{2}$ og $\mathrm{P}_{3}$ er markert. Basert på data fra Becker \& Reinvang (9) 
Marius Kalsås Worren har reist spørsmålet om hvilken norsk betegnelse som bør brukes for elektriske potensialer som oppstår i forbindelse med kognitiv prosessering av stimuli og som registreres på skallens overflate (1). På engelsk betegnes dette nevrofysiologiske fenomenet som «event-related potentials» (ERP) (므). Det engelske begrepet brukes også i norske publikasjoner $(3,4$.). Worren argumenterer med at sammenhengen mellom presentert stimulus og registrert potensial ikke alltid er direkte, og foreslår derfor begrepet «hendelsesrelaterte potensialer» (1).

«Event-related potentials» er nok heller lite kjent i medisinske miljøer, og undertegnede synes så langt å være en av få leger i Norge som bruker metoden i større grad (5). Metodologisk er det små forskjeller fra det mer kjente «evoked potentials»(EP): Testpersonen utsettes for repetitive stimuli mens man registrerer EEG. Via gjennomsnittsberegning kommer man frem til den elektriske aktiviteten som står i sammenheng med presentert stimulus.

Skillet mellom ERP og EP har ikke minst historiske grunner. Mens EP er blitt en etablert metode i det medisinske fagområdet klinisk nevrofysiologi, er ERP tradisjonelt blitt brukt mest i psykologisk forskning. Disse to tilnærmingene er interessert i ulike typer potensialer: EP omhandler tidlige potensialer (opptil ca. $100 \mathrm{~ms}$ etter stimulusbegynnelse). Psykologisk forskning er mest interessert i senere, kognitive prosesser. Tidlige potensialer er først og fremst definert av stimulusegenskaper og betegnes derfor også som «eksogene». Senere aktivitet som reflekterer mer kognitive prosesser, kalles gjerne for «endogene». Overgangen er imidlertid flytende (2). ERP er spesielt egnet til å studere små tidsforskjeller i kognitiv prosessering som kan være relevant å undersøke også i klinisk sammenheng (4).

Norsk forening for klinisk nevrofysiologi omtaler EP og ERP som «fremkalte responser» (므). Dette står i motsetning til Tidsskriftets ordliste. Der anbefales «reaksjonspotensialer» for EP, mens ERP ikke er spesifikt omtalt (.7.). Både «reaksjonspotensial», «fremkalt» og «respons» er imidlertid problematisk som betegnelser for endogene potensialer, fordi disse i stor grad er påvirket av stimulusuavhengige prosesser i hjernen. For eksempel kan svært ulike potensialer forekomme med samme stimulus avhengig av pågående oppmerksomhetsprosesser. Faktisk er det nettopp ERP-metoden som har bidratt mye til erkjennelsen om at stimulusprosessering påvirkes av såkalte ovenfra-ned-prosesser allerede svært tidlig, f.eks. 20-50 ms etter stimulusbegynnelse ( $\underline{8})$. Med dette som bakgrunn burde ERP betegnes som «hendelsesrelaterte potensialer», slik Worren foreslår (11). I forhold til å fastslå årsakssammenheng mellom stimulus og det observerte potensial er betegnelsen forsiktig.

Det synes sannsynlig at ERP etter hvert kan bli en del av det regulære klinisk nevrofysiologiske tilbudet, spesielt som funksjonsdiagnostikk. Dette, kombinert med at EP og ERP i utgangspunktet er samme metode og at sammenhengen mellom stimulus og nevral aktivitet ikke alltid er direkte, taler for bruk av betegnelsen «hendelsesrelaterte potensialer» for all elektrisk aktivitet som oppstår i relasjon til stimuli, dvs. også EP.

\section{Oppgitte interessekonflikter:}

Ingen

\section{LITTERATUR}

1. Worren MK. Hendelsesrelaterte potensialer. Tidsskr Nor Legeforen 2010; 130: 6o.

2. Handy TC. Event-related potentials. A methods handbook. Cambridge: MIT Press, 2005.

3. Becker F. Afasi og plastisitet - hvordan språkbearbeidelsen i hjernen kan endre seg etter skade. Norsk Tidsskrift for Logopedi 2009; nr. 1: 8-12.

4. Solbakk A-K, Reinvang I, Lindgren M. «Event-related potentials» i klinisk nevropsykologi. Tidsskrift for Norsk Psykologforening 2003; 40:109-18. 
5. Becker F. Auditory perception and language comprehension in aphasia - an event-related brain potentials (ERP) study. Doktorgradsavhandling. Oslo: Det medisinske fakultet, Universitetet i Oslo, 2009 .

6. Norsk forening for klinisk nevrofysiologi. Retningslinjer for metoder i klinisk nevrofysiologi del 1. www.legeforeningen.no/id/45109.o (16.3.2010).

7. Tidsskrift for Den norske legeforening. Ordliste. www.tidsskriftet.no/?nota_id=51(22.2.2010).

8. Woldorff MG, Hillyard SA. Modulation of early auditory processing during selective listening to rapidly presented tones. Electroencephalogr Clin Neurophysiol 1991; 79: 170-91.

9. Becker F, Reinvang I. Successful syllable detection in aphasia despite processing impairments as revealed by event-related potentials. Behav Brain Funct 2007; 3: 6.

Publisert: 6. mai 2010. Tidsskr Nor Legeforen. DOI:10.4045/tidsskr.10.0241

Manuskriptet ble mottatt 23.2. 2010 og godkjent 16.3. 2010. Medisinsk redaktør Raida $\emptyset$ degaard.

(C) Tidsskrift for Den norske legeforening 2023. Lastet ned fra tidsskriftet.no 26. april 2023. 